\title{
O DESMENTIDO DA PRIVAÇÃO NA ATUALIDADE
}

Rogerio Quintella

Rogerio Quintella

Psicanalista.

Professor adjunto da Universidade Federal Fluminense (PUCG). Doutor e mestre em Teoria Psicanalítica (PPGTP/UFRJ).
RESUMO: Pretende-se introduzir o termo desmentido de privação, propondo com este definir uma modalidade defensiva própria da contemporaneidade. O artigo situa esta posição defensiva como índice da evanescência do ideal do eu na atualidade. Para tal, analisa-se o conceito de privação em Lacan e sua implicação na formação do ideal do eu, discutindo sobre a função paterna na constituição do sujeito contemporâneo.

Palavras-chave: Privação, desmentido, ideal do eu, função paterna, sintomas contemporâneos.

ABSTRACT: The denial of deprivation in present time. This article introduces the term denial of deprivation, proposing a definition of defense modality which is typical of contemporaneity and it places this defense position as the evanescence index of the ideal ego nowadays. For this purpose, it analyzes the concept of deprivation in Lacan and its implication in the formation of the ideal ego, discussing about the paternal function in the constitution of the contemporaneous subject.

Keywords: Deprivation, denial, ideal ego, paternal function, contemporaneous symptoms.

DOI - http://dx.doi.org/10.1590/S1516-14982016000100008 


\section{INTRODUÇÃO}

Este artigo se dedica a uma reflexão teórica pormenorizada sobre o conceito de privação em Jacques Lacan, para discutir as implicações teórico-clínicas que envolvem novas formas de responder ao mal-estar na cultura. Muito se tem discutido acerca de sintomas que despontam como modalidades diferenciadas de sofrimento em comparação aos sintomas investigados por Freud no início do século XX, tal como apontam Birman (1999), Melman (2003), Lebrun (2009), e outros, a respeito da preponderância de patologias, como a toxicomania, a depressão e as compulsões na clínica contemporânea. Cabe assinalar que grande parte dos pacientes que hoje buscam tratamento apresentam, na base de seu sofrimento, experiências de excesso implicadas na forma como essas patologias se organizam.

Nosso objetivo é propor um olhar sobre esta temática, especialmente no que tange à questão do excesso na experiência do sujeito contemporâneo, partindo especificamente da importante relação entre o ideal do eu e a privação — elementos intrínsecos à constituição do sujeito que, tal como procuraremos demonstrar, aparecem hoje de maneira extremamente peculiar. Esta análise será feita com base nos postulados psicanalíticos capazes de fornecer avanços sobre o tema.

Nossa hipótese se dirige à existência de uma modalidade defensiva própria do sujeito contemporâneo, que se encontra na base dessas experiências, guardadas todas as devidas especificidades sintomáticas e psicopatológicas que as distinguem ${ }^{1}$. Tal modalidade defensiva a denominamos aqui desmentido da privação. Este termo caracteriza, tal como demonstraremos, um dos mais importantes modos de defesa na contemporaneidade, bem como um índice da evanescência do ideal do eu e dos modelos de cultura hoje. Para adentrar esta questão, analisaremos adiante o conceito de privação em Lacan e sua implicação na formação do ideal do eu, discutindo sobre a função paterna na constituição do sujeito contemporâneo.

\section{IDEAL DO EU E PRIVAÇÃO NA DINÂMICA EDIPIANA: O ÉDIPO FREUDIANO RELIDO POR LACAN}

Situarmos uma modalidade defensiva própria da contemporaneidade exige uma reflexão rigorosa sobre os fatores que envolvem o lugar do pai na constituição do sujeito segundo Lacan, dado que encontramos cunhada ali a noção de privação

\footnotetext{
${ }^{1}$ A noção de defesa foi trabalhada por Freud em diversos momentos de sua obra no sentido de caracterizar forças psíquicas que desviam da consciência conteúdos ideativos ou representantes pulsionais que não se compatibilizam. Em "Inibições, sintomas e angústia”, Adendo A(c), Freud (1926/1996, p.158-159) distingue o termo "método defensivo" de "técnica defensiva". Define como "método" a defesa que funda a neurose (recalque); e como "técnicas defensivas" as defesas em geral que aparecem na neurose de maneira variável. O tipo de defesa que abordaremos aqui é correlato do termo "técnica defensiva", e se distingue da concepção de regime fundante que define cada uma das estruturas clínicas (recalque, rejeição, recusa).
} 
como um dos elementos-chave da relação do homem com o desejo, bem como das questões que acreditamos girar em torno da experiência subjetiva contemporânea.

Considera-se que, do ponto de vista da constituição do sujeito segundo Lacan, é o caráter intrínseco da perda do objeto - inscrição do sujeito no universo da falta, do desejo e da finitude - o que está em jogo na travessia do complexo de Édipo. Em Lacan, a relação entre Édipo, privação e ideal do eu está presente desde o início de sua releitura da obra de Freud, e isso fica claro quando situa na significação fálica a dialética relacionada à formação do ideal. O falo aparece, em sua abordagem, como objeto do desejo da mãe, com o qual a criança a princípio se identifica.

Por outro lado, em suas primeiras considerações, Lacan já assinalava que não há Édipo sem pai, assumindo este a função de fundar a lei no Outro. Este último conceito - grande Outro - é definido por Lacan como lugar simbólico onde "repousa" o sistema significante, de onde se organiza a lei do desejo. Nesse nível, o pai funciona inscrevendo no lugar do Outro a lei que engendra o desejo. Lacan aborda o complexo de Édipo distinguindo três tempos lógicos que compõem a relação do sujeito com o desejo a partir da castração.

Para adentrar esta questão, Lacan se utiliza, como faz em toda sua obra, da tríade Imaginário, Simbólico, Real, retomando o pai nesses registros (pai real, pai simbólico, pai imaginário). Articula ali as dimensões da falta de objeto castração, frustração, privação - buscando distinguir tais dimensões na trama edipiana e na relação ao pai. ${ }^{2}$

Assim, no primeiro tempo do complexo de Édipo assinala-se a posição de objeto do desejo da mãe ocupada pela criança; mirando o desejo da mãe, a criança constrói a fantasia de assassinato do pai, buscando ser o próprio falo. Nesse momento o pai não aparece, a não ser de maneira velada. Trata-se aí do pai simbólico, um significante (Nome-do-pai) que interdita a mãe, sendo capaz de substituir o significante materno na cadeia, produzindo a metáfora.

O pai simbólico é pai morto, naquilo que proíbe a mãe à medida que a mesma não pode ser tomada como objeto de satisfação da criança, instaurando-se desde já a ordem simbólica implicada na lei que promove a transmissão da castração — barra do gozo absoluto que engendra o desejo, instaurando na criança uma frustração imaginária na relação com o desejo da mãe. Essa proibição se dá no nível da fantasia de parricídio que, ao invés de abrir caminho para o gozo absoluto, torna este definitivamente impossível pela barra da lei simbólica, implicando o sujeito na incompletude, e inscrevendo este mesmo sujeito como desejante. "Esta é a etapa fálica primitiva, aquela em que a metáfora paterna age por si, uma vez

\footnotetext{
${ }^{2}$ A exposição que se segue refere-se a uma revisão da teoria lacaniana sobre o complexo de Édipo e visa fundamentar nossa concepção para o desenvolvimento do tema a ser abordado posteriormente.
} 
que a primazia do falo já está instaurada no mundo pela existência do símbolo do discurso e da lei" (LACAN, 1957-1958/1999, p.198). É sob os auspícios da culpa parricida que a lei simbólica do pai enuncia a interdição do incesto. Instaura-se a lei num lugar que vai além da relação falo-mãe-criança.

No segundo tempo trata-se de remeter a mãe à lei à medida que o pai imaginário funciona privando a mãe, esta última fundando, em seu próprio discurso, a lei simbólica. Aqui a lei, já se achando inscrita no Outro, é tomada no discurso da mãe como aquilo que confere ao pai um lugar de exceção. O pai no segundo tempo é o pai onipotente, à medida que priva a mãe impedindo a criança de permanecer em posição de objeto. Nesse nível, o sujeito submete-se à onipotência do pai, sendo arrebatado de uma suposta onipotência frente ao desejo materno.

O terceiro tempo "sucede a castração e a privação" (idem, p.201), e nele se observa exatamente o denominado declínio do complexo de Édipo:

“É por intervir no terceiro tempo como aquele que tem o falo, e não que o é, que se pode produzir a báscula que reinstaura a instância do falo com o objeto desejado da mãe, e não mais apenas como objeto do qual o pai pode privar. (...) Aqui intervém, portanto, a existência da potência no sentido genital da palavra - digamos que o pai é um pai potente." (LACAN, 1957-1958/1999, p.200)

É exatamente esse pai potente - única exceção à regra porque suposto detentor do falo - que será o suporte da lei (aquele que a "suporta") abrindo caminho para a identificação ao ideal do eu, e atestando o valor da Ordem Simbólica inscrita no primeiro tempo. Na instauração do ideal do eu se intercambiam pai real e pai imaginário castrador e privador - à medida que, na passagem do segundo para o terceiro tempo, o sujeito, privado de ser o falo da mãe, ancora-se nesse pai real que a satisfaz sexualmente, conduzindo-se a uma saída mediante o ideal. Funda-se aí a figura da autoridade à medida que, para não perder o amor do pai ideal, o sujeito se submete a ele, divinizando-o (FREUD, 1933/1996). Lacan conclui: "Esse pai imaginário, é ele, e não o pai real, que é o fundamento da imagem providencial de Deus" (LACAN, 1959-1960/1997, p.369).

Cabe dizer que a Ordem Simbólica, inscrita no primeiro tempo, adquirirá seu valor para o sujeito no terceiro tempo, na instauração do ideal do eu, à medida que o menino toma para si o traço do pai, colocando o "título no bolso" e a menina organiza a dialética desejante, buscando na relação com o pai o objeto do desejo (LACAN, 1957-1958/1999).

Temos, portanto, a passagem do segundo para o terceiro tempo como aquilo que produz no sujeito a saída do Édipo à medida que a privação funciona como mola do ideal do eu. Lacan (1957-1958/1999, p.178) afirma: “o nível da privação intervém na articulação do complexo de Édipo. Trata-se então do pai como aquele que se 
faz preferir em lugar da mãe, dimensão que vocês são absolutamente forçados a fazer intervir na função terminal, aquela que leva à formação do ideal do eu". Nesses três níveis, a passagem do segundo para o terceiro tempo engendra o chamado declínio do Édipo, instaurando a identificação ao ideal do eu numa saída que toma como suporte a figura "superior" do pai, aquela que perfila os traços e valores a serem introjetados nesse processo identificatório. Lacan assevera: “É por intervir como aquele que tem o falo que o pai é internalizado no sujeito como ideal do eu, e que, a partir daí, não nos esqueçamos, o complexo de Édipo declina" (idem, p.201).

É neste mesmo ideal do eu que o sujeito se ancora buscando ali uma forma de ser, tomada do pai, identificando-se aos traços deste último. Lacan assevera, nas entrelinhas, que este momento introduz para o sujeito o chamado período de latência — e isso assume aqui toda relevância:

\footnotetext{
"Não quer dizer que o menino vai tomar posse de todos os seus poderes sexuais e exercê-los, como vocês bem sabem. Muito pelo contrário, ele não os exerce nem um pouco, e poderíamos dizer que, aparentemente, decai do exercício das funções que haviam começado a despertar.” (idem, ibidem)
}

Sobrevém aqui o indicativo de uma questão que compõe a linha dorsal do presente artigo: Lacan assinala que a criança pode ou não aceitar a privação. É esse o ponto nodal que encontramos na neurose. Indagamos, contudo, em que dimensão essa não aceitação se configura, e quais os destinos disso nas posições assumidas pelo sujeito na atualidade.

\section{(RE)PENSANDO A NEUROSE HOJE: A PRIVAÇÃO EM QUESTÃO}

Este estudo é pertinente à reflexão sobre o papel da autoridade na trama edipiana que marca uma diferença importante na constituição do sujeito contemporâneo, especialmente no que tange à instauração do ideal do eu. É cada vez mais evidente o esfacelamento da autoridade do pai na trama familiar desde a desconstrução do patriarcado e da emergência do discurso da ciência (LEBRUN, 2009).

Assim, Pinheiro, Quintella e Verztman (2010) assinalam que o modelo de cultura vigente apresenta como uma das marcas preponderantes um autocentramento subjetivo que marca a prevalência da imagem de si, subjugada à fantasia primária de onipotência narcísica, característica de uma busca pelo imediatismo da satisfação pulsional. Esta fantasia se acha implicada no que Leclaire (1975) denominou "Criança Maravilhosa" e parece substituir qualquer possibilidade de 
projeção num futuro possível, sustentado pelo ideal do eu. ${ }^{3}$ A condição desejante aparece na contemporaneidade, segundo esses autores, como a mais insuportável condição, especialmente numa cultura em que a exacerbação da imagem narcísica e a busca pelas satisfações e soluções imediatas evidenciam-se como cena fundamental da existência humana (idem). Nessa concepção, a subjetividade sustenta-se hoje muito mais implicada na referência imagética da Criança Maravilhosa do que na internalização de ideais rígidos e predefinidos, oferecidos por representantes da cultura na família, tal como acontecia preponderantemente até a primeira metade do século XX.

Para avançar sobre esta questão cabe frisar que, tal como se constata em muitos casos da clínica atual, o ideal do eu aparece numa condição que podemos chamar de evanescência, e o sujeito não encontra espaço psíquico no sentido de forjar para si um ideal do eu constituído por uma figura "assimétrica" — mais especificamente o pai — que lhe dê sustentação para as identificações secundárias. Entende-se com isso uma fugacidade na identificação secundária edipiana que não implica o pai como sustentáculo dessa identificação. Esta condição não faz referência à organização psicótica - não se trata de foraclusão. A circunstância em pauta se situa num nível em que o sujeito, inscrito na lei do desejo, responde na contramão deste último, posicionando-se sintomaticamente perante a evanescência do ideal do eu na trama edipiana. Nessa circunstância, não é a figura do pai o que entra no lugar do ideal do eu. O sujeito coloca no lugar do ideal do eu a própria fantasia de onipotência narcísica, subjugada à representação primária da Criança Maravilhosa, cujo corolário é a gama de sofrimentos que despontam na contemporaneidade, implicados em experiências de excesso e em sintomas depressivos.

Sobre isso é interessante pontuar o lugar que a depressão vem assumindo na constituição sintomática atual. Pinheiro, Quintella e Verztman (2010) diferenciam a depressão do luto e da melancolia, definindo a primeira como resultado do fracasso da fantasia de onipotência narcísica. Distinta da melancolia, que apresenta no cerne de sua organização a identificação maciça ao objeto perdido (FREUD, 1917/1996), a depressão é um sintoma neurótico que responde à impossibilidade de sustentação da imagem da Criança Maravilhosa no universo do desejo, num impasse sintomático intrínseco à evanescência do ideal do eu na contemporaneidade. Nessa concepção, a depressão não se reduz ao afeto da tristeza, dado que assume um caráter defensivo, resultando em sintomas graves de estagnação, desinvestimento, conflitos com a imagem de si — sintomas que

\footnotetext{
3 A Criança Maravilhosa é um conceito desenvolvido por Leclaire que caracteriza o fundamento da experiência primária do narcisismo. Ela aparece como posição subjetiva à qual o sujeito é convocado a renunciar mediante a instauração do luto, a fim de sustentar sua condição desejante. A renúncia à Criança Maravilhosa funciona atrelada à instauração do ideal do eu que opera, tal como reverberou Freud (1914/1996), o afastamento do narcisismo primário.
} 
às vezes culminam em atos suicidas. A depressão aparece como uma das mais pregnantes formas de sofrimento na atualidade ante a evanescência do ideal do eu.

Nesse ponto, é necessário assinalar que o conflito não se dá tanto em torno de uma medida superegoica em função do ideal do eu (FREUD, 1933/1996) um ideal "bem definido", assimétrico, tomado da figura do pai. Hoje o que se constata preponderantemente é um sujeito desbussolado, tal como aponta Miller (2004), um sujeito que não lança mão de uma ancoragem ideal para buscar um caminho a seguir no campo do desejo, apresentando uma relação peculiar com o supereu e uma posição subjetiva que implica um "desnorteamento" na busca pela satisfação pulsional.

Com efeito, trata-se de sujeitos que, buscando uma saída para a castração, apresentam um modo específico de defesa — são sujeitos quenão se furtam a buscar na imagem perdida o triunfo derradeiro da onipotência, deprimindo violentamente, muitas vezes, diante de seu fracasso. Esta modalidade defensiva é característica de um enredo subjetivo peculiar, relativo à privação edipiana, à medida que esta última é entendida por Lacan (1957-1958/1999) como mola do ideal do eu. O lugar disto na constituição do sujeito no que tange à modalidade defensiva ali determinante será objeto de nosso aprofundamento adiante.

\section{O DESMENTIDO DA PRIVAÇÃO}

Dissemos acima que, na atualidade, a clínica revela um sujeito "desbussolado", desorientado no que tange àquilo que o determina como sujeito, bem como ao modo de se relacionar com o gozo (MILLER, 2004). Esta concepção caracteriza as peculiaridades do sujeito frente à organização psíquica do tempo de Freud, e de uma forma mais radical, dos dias de hoje. O que se constatava na modernidade era uma contestação neurótica ao ideal, resultado do discurso da ciência e do declínio do poder da Igreja, atingindo a família e o patriarcado no seu epicentro. Conforme aponta Machado, numa pesquisa sobre o tema:

"O declínio do poder de Deus, da religião e da Igreja atingem a vida social, política e familiar. A moral vai perdendo força como o bem maior de um indivíduo. É nesse contexto que a psicanálise surge, orientada pelos conflitos em relação ao pai e à moral. (...) Sua autoridade é questionada e isto faz sintoma." (MACHADO, 2005, p.17)

A mesma autora situa: "Se, na modernidade os ideais eram contestados, na contemporaneidade eles perderam valor" (idem, p.18).

Como dissemos, na atualidade os modelos ideais, que antes norteavam o sujeito na relação com a satisfação pulsional, perdem lugar, desvanecem, ou não assumem valor, instaurando mais intensamente o sentimento de desamparo. 
Hoje, o sujeito é lançado, consequentemente, a uma instabilidade mais acentuada. Assim, os modelos ideais, que alicerçavam um código predefinido sobre os caminhos a serem trilhados, acham-se substituídos por uma perseguição da unidade imagética do eu, bem como uma busca pelo imediatismo da satisfação pulsional, conforme sublinhamos antes.

Ora, é à medida que o Édipo declina com a formação do ideal do eu que o sujeito conjuga para si um modelo identificatório intrínseco à organização de uma posição erógena na cultura. Perfilado pela evanescência atual dos ideais, e “desbussolado”, tal como aponta Miller, o sujeito atira-se hoje, muitas vezes, a um imperativo de gozo que implica outro tipo de posição subjetiva na relação ao limite. ${ }^{4}$

Trata-se de uma peculiaridade na relação ao pai tomado como ideal do eu, o qual encontra na travessia edipiana sua condição de possibilidade. Note-se que o ideal do eu, movido pela privação edipiana — o pai como preferível à mãe — funciona como sustentáculo do afastamento das representações narcísicas primárias, dando suporte à elaboração do luto. O luto é um trabalho de simbolização; ele tem como desfecho a identificação aos traços do ideal e como resultante uma modificação no eu — transformação sustentada pelo ideal do eu (FREUD, 1923/1996). Esta condição se instaura à medida que o sujeito busca na imago paterna um esteio identificatório capaz de dar suporte e abrir caminho para novos investimentos objetais. Lacan (1957-1958/1999, p.191) salienta que “(...) toda privação real exige simbolização”. É a partir disso que o luto será mobilizado — de um lado o luto da Criança Maravilhosa, ancorado no ideal do eu; de outro, o luto do próprio pai ideal, à medida que, no real, o pai nunca está à altura de garantir o fundamento do ser do sujeito, sequer garantir o sucesso nas investidas amorosas do sujeito vida afora, sendo este último convocado, diante da castração, a assumir e sustentar uma posição desejante singular.

Diante da evanescência do ideal, o luto fica cada vez mais colocado à margem, o que leva o sujeito a reações sintomáticas peculiares. A depressão é uma dessas reações cujo caráter, diferentemente do luto, vai na contramão do desejo.

Para avançar sobre essa questão, propomos pensar uma condição subjugada ao fracasso do pai em posição de ideal do eu. Sobre esta problemática, cabe assinalar precisamente isto: o pai, no terceiro tempo do Édipo, não se apresenta como detentor do falo para a criança, ou esta última não atribui a ele o direito de sua posse.

Trata-se aqui de uma circunstância subjetiva que pode resultar numa defesa cuja especificidade implica a relação do sujeito com a privação diante da

\footnotetext{
${ }^{4}$ Lacan (1973/1993) aborda o "imperativo de gozo" como uma obrigação interna imposta pelo supereu, que implica um empuxo ao gozo absoluto como resposta à impossibilidade de aceder ao lugar do pai simbólico. Veremos adiante a especificidade disso na atualidade.
} 
fugacidade identificatória ao ideal. Assinala-se nesse ponto uma saída defensiva peculiar, característica de uma ruptura precoce com o pai ideal.

Esta é uma faceta neurótica defensiva que propomos denominar desmentido da privação.

O desmentido da privação é um modo de defesa que encontra apoio na crença do pai impotente - "impotente" diante satisfação materna. A circunstância subjetiva que ali se assinala responde à evanescência do ideal do eu que, no nível da modalidade defensiva em pauta, caracteriza um mergulho na imagem da Criança Maravilhosa cujo capricho empurra o sujeito para experiências de excesso: as compulsões desmedidas e/ou a depressão aguda.

A nuance em relação aos sintomas clássicos da neurose é que o supereu funciona não tanto como força imperativa de um gozo engendrado pela autopunição que antes prevalecia na neurose obsessiva, ou pelo "gozo da privação" tal como aparece no sintoma histérico clássico (QUINET, 2003), mas por um imperativo de gozo característico das experiências de excesso tão presentes na clínica contemporânea. No contexto dessa nuance, constata-se um enfraquecimento do período de latência à medida que o pai não aparece como detentor do falo no declínio do Édipo.

Não é por acaso que na atualidade a vida sexual é retomada cada vez mais cedo, quase num processo de apagamento do período de latência. O desmentido da privação, que não implica ausência de privação, mas caracteriza uma forma de defesa que prepondera na atualidade, redunda num empuxo ao gozo, bem como num mergulho ao imediatismo da satisfação pulsional. Nessa circunstância, o supereu não funciona comparando o eu com seu ideal, tal como Freud descrevia quando falava da relação entre essas duas instâncias (FREUD, 1933/1996).

O supereu parece não encontrar hoje respaldo nos valores mediados pelo ideal para sustentar sua punição ao eu e satisfazer o masoquismo moral. Na clínica atual o supereu, desatrelado do ideal do eu, aparece muito mais desmedido, violento ou compulsivo - figura do supereu que Zizek (1999) aponta como sendo a própria raiz obscena da voz imperativa que exige, irracionalmente, o gozo sem medida ou cálculo que adie o encontro do sujeito com a própria morte.

A agressividade culposa a que Freud (1930/1996) se refere na relação à autoridade e na constituição da exigência superegoica, passa a ser dirigida menos ao eu e mais intensamente dirigida para objetos externos, no nível da compulsão, numa tentativa desesperada de introjeção no lugar da identificação ao ideal do eu. Diante do pai negado como ideal, há nesses casos o desmentido da privação num movimento defensivo que tem como objetivo último desviar-se da castração.

O termo "desmentido" (Verleugnung) não alude, nesses casos, à recusa perversa. O perverso recusa a própria castração, situando-se, com isso, numa estrutura. $\mathrm{Na}$ perversão o sujeito desmente a lei simbólica no primeiro tempo edipiano, característico da inscrição do sujeito no universo da falta (LACAN, 1957-1958/1999). 
O sujeito perverso age como se a lei não estivesse ali, desmentindo a falta de pênis na mãe e a inscrição da lei no Outro.

O desmentido da privação é um aspecto da neurose na contemporaneidade o sujeito não desmente a lei propriamente dita como faz o perverso, mas nega o pai como ideal, desmentindo a privação, e situando aí uma saída neurótica, diferenciada. Nesses casos, a lei simbólica promoveu seus efeitos neuróticos no que tange à castração ao nível do primeiro tempo edipiano — o sujeito não recusa a castração e inscreve-se no regime do recalque. Ele se submete à castração e à lei simbólica, mas desmente a privação que engendra o ideal do eu na passagem do segundo para o terceiro tempo edipiano - o que o leva ao desnorteamento e a conflitos que assumem hoje importantes dimensões na relação com o desejo e o gozo.

Nesse âmbito, o desmentido da privação evidencia o que hoje é notável: o sujeito age muitas vezes como se pudesse tudo — o que o faz "parecer-se" com um sujeito perverso. ${ }^{5} \mathrm{O}$ sujeito age como se o objeto da satisfação absoluta estivesse à mão, exposto numa vitrine, ou diretamente disponível nos círculos sociais. Pode, supostamente, sair pelos espaços sociais e fazer o que quiser, contudo não o faz sob o cálculo perverso, mas o faz impulsivamente, ou mesmo compulsivamente; droga-se, por exemplo, sem consequências visíveis, busca relações sexuais sem limites aparentes, entrando muitas vezes num circuito compulsivo ou mesmo violento, característico de um gozo que extrapola a busca pelo prazer. A depressão é a marca do fracasso neurótico dessa modalidade defensiva, posto que a tentativa de anular a privação não conduz o sujeito à felicidade, mas assinala ali mesmo a incompletude do sujeito e a "incurabilidade" da castração, redirecionando o mesmo ao funcionamento além do princípio do prazer, preponderante no sofrimento depressivo, e/ou nas compulsões atuais (compulsão ao consumo, ao status corporal, à beleza, aos alimentos, e outras).

Salienta-se aí uma mudança, apontada por Miller (2004), que instaura o ideal como submetido ao gozo do objeto. Esta condição não redunda, portanto, no desaparecimento absoluto do ideal, mas nivela este último a uma fugacidade constante de experiências e mercadorias ofertadas no socius como possibilidade suposta de encontro com o objeto perdido. É nesse nível que definimos o ideal do eu como evanescente.

Logicamente, a apreensão sobre o Édipo e os três tempos que ele engendra - período em que Lacan dava ênfase ao simbólico e focava sua teoria na apreensão do sujeito como efeito da operação do significante — não é suficiente

\footnotetext{
${ }^{5}$ Birman (1999) situa a toxicomania, por exemplo, do lado da estrutura perversa, defendendo a recusa da castração como regime de funcionamento ali presente. Numa concepção próxima desta, Jammet (1993) situa as compulsões bulímica e anoréxica também no campo da organização perversa. Direcionamo-nos a uma concepção diferenciada - não se trata de desmentir a lei simbólica, mas a privação que articula o ideal do eu.
} 
para situar os aspectos do sintoma no que se refere à satisfação pulsional, ao gozo e ao que escapa à aparelhagem simbólica. Estes últimos aspectos aparecem hoje de maneira muito mais notável do que aquela abordada pela decifração psicanalítica do tempo de Freud, e repensada por Lacan no início de seu ensino, em que a categoria do "gozo fálico" mapeado pelas condensações faz prevalecer, via sintoma, as formações simbólicas como formas de responder ao enigma do desejo do Outro.

O avanço de seu ensino, que não abandonou a abordagem sobre a função paterna, mas proporcionou novos investimentos teóricos sobre o tema, abriu caminho para a formulação do conceito de gozo. Esta apreensão vai além da teoria do significante, tratando o simbólico como campo que engendra uma falha estrutural, à medida que o significante não é capaz de representar plenamente o sujeito, instaurando-se aí mesmo o desejo como marca da impossibilidade de plenitude e o próprio gozo como resto da operação significante (LACAN, 1969-1970/1992).

A introdução do conceito "mais-de-gozo" é um dos importantes avanços sobre a teoria de Lacan acerca da relação significante/gozo. Na época em que colocava ênfase no significante fálico como barra do gozo e função do desejo, Lacan destacava o caráter interditor da função paterna. Em 1970, Lacan assinala que “o assassinato do pai é a condição do gozo” (LACAN, 1969-1970/1992, p.113), abordando o mais-de-gozar como algo que implica, por um lado, a renúncia primeira, numa dimensão em que a perda faz aparecer o objeto a como causa de desejo; e, por outro lado, implica como resposta à perda de gozo, uma dimensão em que a própria renúncia reforça e fortalece a exigência superegoica. Essa forma de gozo, que implica a renúncia e a perda como marcas constitutivas do sujeito, aparece na dimensão de um resto suplementar a ser recuperado — resto que excede ao nível do imperativo superegoico — goza!

Cabe salientar assim que, no que se refere à atualidade, não se trata de pensar um gozo absoluto ou "desenfreado" — o que redundaria no fim da própria civilização. Não é por acaso que muitos desses sintomas engendram um apelo ao pai como tentativa de encontrar um limite que remete o sujeito à renúncia primordial e à própria barreira do incesto. Esse apelo dirige-se a experiências de excesso cuja outra face é a busca pelo limite, ainda que encontrado muitas vezes na própria morte.

Situa-se aqui um paradoxo: por um lado, a metáfora paterna promove a interdição do gozo, por outro, ela é a própria condição do gozo (idem), cujo empuxo insiste em se fazer presente como medida transgressiva através dos apelos à função paterna que se atualizam permanentemente, numa tentativa desesperada de fazer a lei assumir ali seu valor.

As experiências de excesso aqui mencionadas ganham relevo ainda maior nos dias de hoje, com algumas peculiaridades subjacentes ao fracasso do pai em 
posição de ideal: trata-se de um sujeito interditado, inscrito na nomeação do desejo, mas cujo pai fracassa ao nível do ideal do eu. Se o pai hoje não funciona como suporte do ideal, é justamente porque fracassa em apresentar-se como preferível à mãe — o pai privador. Este último evanesce cada vez mais como índice concomitante do fracasso do pai no terceiro tempo - o pai como potente, suposto detentor do falo. Não obstante a presença da lei — a inscrição simbólica da interdição e da triangulação objetal, que se articula na neurose, o sujeito empurra-se ainda mais ao gozo que extrapola as formações simbólicas, apesar de achar-se inscrito no circuito neurótico. ${ }^{6} \mathrm{O}$ apelo ao pai, no caso dessas experiências contemporâneas em que o desmentido da privação aparece como modo de defesa preponderante, é a contrapartida intrínseca à Criança Maravilhosa que, sobrepujando o ideal do eu, marca uma suposta ausência de limites ou de privações, e ao mesmo tempo assinala o lugar da lei como ponto de basta na relação com o gozo.

Sendo assim, o que está em questão é o traço do ideal do eu captado de um pai a princípio potente e privador, um pai que é suposto detentor do falo — lugar de exceção, que norteia o caminho para a identificação ao ideal do eu. É exatamente nesse ponto que insistimos a respeito das nuances desse "fracasso", dado que a falha no Outro é estrutural. Trata-se do fracasso do pai enquanto suporte do ideal, suposto detentor do falo no terceiro tempo edipiano. Diante do lugar de exceção colocado "sob rasura”, se assim podemos nos expressar, o ideal do eu fica negado, e o sujeito dá de frente com o pai real "impotente”, desnorteando-se na busca pela satisfação. Responde a isso, muitas vezes, desmentindo a privação e atualizando a fantasia de onipotência narcísica, que se furta a sustentar o trabalho de luto. Sobrepõe-se no discurso do sujeito o desmentido da privação como modo de defesa cujo germe é a fantasia de onipotência tomada pelo extremo: a busca pelo excesso e sua contrapartida depressiva. Engendra-se nesse nível uma saída defensiva que, diferentemente do "gozo da privação" histérico, no qual o sujeito mantém vivo o desejo insatisfeito, gozando com a privação, coloca o sujeito numa relação de "tudo ou nada" que, em última análise, desmente a privação.

Diante da castração, o sujeito contemporâneo engendra um discurso peculiar: "se não sou tudo, se não tenho tudo ou não posso tudo, tomo em meu ato o caminho do nada, ou até mesmo da morte."

\section{CONCLUSÃO}

Essas considerações marcam a necessidade de um exame pormenorizado da função paterna na atualidade, o que tem sido situado na linha de frente das prin-

\footnotetext{
${ }^{6}$ Portanto, não incluímos nesta discussão sobre as experiências de excesso os casos de psicose, nos quais o que se acha em questão é a foraclusão.
} 
cipais discussões sobre a psicanálise contemporânea. Assim, é importante situar, antes de tudo, no pai simbólico a função de nomeação, característica da entrada do sujeito no campo do desejo, à medida que ali se promove a transmissão da castração, fundando-se o interdito como condição da civilização.

Não seria o caso então de considerar sob esse ponto de vista que o simbólico, com suas falhas estruturais, continua a produzir seus efeitos de inscrição da castração a partir da lei, situando a neurose no contexto da formação do laço social? A civilização não foi nem está sendo suprimida. O que muda é a diversificação na forma como esse laço social se constitui à medida que produz modalidades diferenciadas de sintomatização ou de enfrentamento do mal-estar. Cabe afirmar que as tentativas de ligação nas experiências de excesso (que, além do princípio do prazer, culminam na depressão e nas compulsões atuais), não obstante uma tendência contemporânea à dissolução do laço social (HERZOG, 2003), insistem na busca pelo limite, muitas vezes implicada no "apelo ao pai”. Sendo assim, não se trata de abordar a questão pelo lado da "falência do simbólico" ou da dissolução do laço social, mas de modalidades outras de laço, ou formas de ligação na economia do gozo e seus imperativos.

O que está em questão hoje, a nosso ver, é o declínio da autoridade no nível do ideal do eu — não da lei simbólica que engendra o desejo. É o declínio da imago paterna que, desde o desmonte do patriarcado e do poder da Igreja, com o advento da ciência, apresenta como corolário as formas de gozo na modernidade e na contemporaneidade. Se não como um dos nomes-do-pai, a imago paterna na contemporaneidade não poderia sofrer, no terceiro tempo do Édipo, sua própria falência ao nível do ideal. ${ }^{7}$ Portanto, sendo a falha no simbólico constitutiva do sujeito, o que muda não é propriamente a estrutura do simbólico, mas a forma como se lida com a falha. Na modernidade era a instauração do ideal com seus alvos de contestação, sobrevindo o sintoma como metáfora do desejo; na contemporaneidade, a falência da autoridade, sobrevindo a fugacidade do ideal na relação com o gozo.

Nesse nível, a evanescência do ideal do eu instaura para o sujeito uma relação diferenciada com a Ordem Simbólica, à medida que o estatuto desta última no terceiro tempo edipiano perde valor, não obstante sua presença. O sujeito, inscrito na Ordem Simbólica, não coloca no bolso o "título do pai”, desnorteando-se diante da privação real e da própria castração. Nessa posição, o sujeito contemporâneo tende ao afastamento de toda referência à poesia.

\footnotetext{
${ }^{7}$ Lacan (1963/2005) relativiza o conceito de nome-do-pai, assinalando as diversas formas pelas quais se pode conceber a ideia de perda de gozo no percurso de constituição do sujeito. Remetemo-nos especificamente à afirmação de Miller, que fundamenta a concepção aqui exposta, de que "o imaginário, o simbólico e o real, eis os verdadeiros nomes-do-pai" (MILLER, 2005, p.8).
} 
Com efeito, isso só vem evidenciar, e de maneira ainda mais contundente, a falha estrutural da própria Ordem Simbólica. Cabe então ponderar que os códigos simbólicos que na modernidade ainda norteavam o sujeito (de certa forma), e assumiam valor de código predefinido em função do ideal, pautando regras de conduta, "certo e errado", submetimento às leis de Estado, formas de relacionamento e gozo etc., descaracterizam-se hoje como códigos "predefinidos" e aceitos coletivamente.

Isso não implica ausência de códigos, nem que esses códigos não possam se reorganizar de outras formas - por exemplo, o modelo de status corporal magro e musculoso perseguido nas academias, muitas vezes compulsivamente; ou o mandato de felicidade por meio de antidepressivos; ou ainda, a ilusão de transformação do privado em público que engendra as exposições na mídia, nos reality shows, etc. Sob esse aspecto, a ilusória "livre escolha absoluta”, ou o aparente "hedonismo permissivo", tão característicos da atualidade são, em essência, imperativos de gozo além do princípio do prazer, paradoxalmente carregados de regras e códigos implacáveis, mas que rapidamente evanescem, abrindo caminho para um novo desnorteamento subjetivo. Resta a cada sujeito hoje estipular ou construir por si mesmo seus próprios valores e ideais diante do supereu que não prescinde do gozo: o obriga. Este mesmo supereu o faz cada vez mais desatrelado do ideal do eu.

Cabe então ponderar que na atualidade o pai, em muitos casos, não funciona como suporte da lei (não a “suporta”), não obstante a presença desta, implicando uma ruptura precoce com o ideal do eu. Definir uma posição diante do desejo se torna, nessas condições, uma tarefa ainda mais difícil, quando o que se vê é um sem-fim de ofertas sociais e mercadológicas que funcionam desmentindo a privação e tentando afrouxar o interdito. Objetos tão fugazes que dificultam muitas vezes a sustentação do próprio desejo na cultura.

As peculiaridades que engendram esse desmentido da privação nas denominadas "patologias do excesso" (compulsões, toxicomania, etc.) exigem aprofundamento pertinente a cada uma delas, evidenciando-se a necessidade de se definir as especificidades sintomáticas e devidas distinções de cada uma. De modo mais preciso, essas formas de sofrimento contemporâneo denotam modos distintos de desmentir a privação, caracterizando de maneira contundente os percalços da vida psíquica na atualidade. Estas questões, circunscritas aos aspectos sintomáticos de nosso tempo, merecem ser aprofundadas num movimento de investigação capaz de lançar luz sobre a neurose na atualidade se quisermos pensar o lugar da clínica psicanalítica perante as formas contemporâneas de gozo no campo do sujeito. 


\section{REFERÊNCIAS}

BIRMAN, J. (1999). Mal-estar na atualidade: a psicanálise e as novas formas desubjetivação. Rio de Janeiro: Civilização Brasileira.

FREUD, S. (1996). Edição standard brasileira das obras psicológicas completas de Sigmund Freud. Rio de Janeiro: Imago.

(1914) "Sobre o narcisismo: uma introdução”. v.XIV, p.77-110.

(1923) “O ego e o id”. v.XIX, p.15-82.

(1926) “Inibições, sintomas e angústia”, v.XX, p.81-174.

(1930) "Mal-estar na civilização”, v.XXI, p.73-150.

(1933) “Novas conferências introdutórias sobre psicanálise”,v.XXI, p.63-84.

HERZOG (2003) O Estatuto da Bindung na contemporaneidade. Interações, v.8, n.16. São Paulo: USM, p.37-56.

JAMMET, P. (1993) L’approche psychanalytique des troubles des condiotes alimentaires. Neuropsychiatrie de l'enfance, v.41, n.56, Paris, p.235-44.

LACAN, J. (1957-1958/1999) O Seminário livro 5, As formações do inconsciente. Rio de Janeiro: Jorge Zahar.

(1959-1960/1997) O Seminário livro 7, A ética da psicanálise. Rio de Janeiro: Jorge Zahar.

(1963/2005) Nomes-do-Pai. Rio de Janeiro: Jorge Zahar.

(1969-1970/1992) O Seminário livro 17, O avesso da psicanálise. Rio de Janeiro: Jorge Zahar.

(1973/1993)O Seminário, Livro XX, Mais, ainda. Rio de Janeiro: Jorge Zahar.

LEBRUN, J-P.(2009) Entrevista: Jean-Pierre Lebrun. Textura Revista de Psicanálise, v.8, n.8. São Paulo: DMM Gráfica.

LECLAIRE, S. (1975) Mata-se uma criança: estudo sobre o narcisismo primário e a pulsão de morte. Rio de Janeiro: Jorge Zahar.

MACHADO, O.M.R. (2005) "A clínica do sinthoma e o sujeito contemporâneo”. Tese de doutorado, Programa de Pós-Graduação em Teoria Psicanalítica, Instituto de Psicologia, Universidade Federal do Rio de Janeiro.

MELMAN, C.O. (2003) Homem sem gravidade: gozar a qualquer preço. Rio de Janeiro: Companhia de Freud.

MILlER, J.-A. (2004) Uma fantasia. Opção Lacaniana, São Paulo: Eolia, n. 42 , p.7-18.

(2005) "Preâmbulo", in LACAN, J. (1963/2005) Nomes-do-Pai. Rio de Janeiro: Jorge Zahar.

PINHEIRO, T. QUINTELLA, R. e VERZTMAN, J. (2010) Distinção teórico-clínica entre depressão, luto e melancolia. Psicologia Clínica, v.22, n.2. Rio de Janeiro: PUC-Rio, p.147-168.

QUINET, A. (2003) "Histeria, sujeito, corpo e discurso", in QUINET (Org.). Anais do I Colóquio da Escola de psicanálise do Campo Lacaniano. Rio de Janeiro: FPCL. 
ZIZEK, S.(1999) O superego pós-moderno. Folha de S. Paulo - Mais! São Paulo: Jornal Folha de São Paulo, p.5-8.

Rogerio Quintella

rrquintella@hotmail.com 